\title{
THE LONG-TERM RELATIONSHIP BETWEEN RENEWABLE ENERGY AND ECONOMIC GROWTH: THE CASE OF AMERICA
}

\author{
DOI: 10.17261/Pressacademia.2021.1499 \\ PAP- V.14-2021(25)-p.113-114
}

\section{Zulal Sezici ${ }^{1}$, Sultan Kuzu Yildirim ${ }^{2}$}

${ }^{1}$ Istanbul Gelisim University, Business Administration, Istanbul, Turkey. zsezici@gelisim.edu.tr, ORCID: 0000-0001-7274-4533

${ }^{2}$ Istanbul University, Quantitative Methods Department, Istanbul, Turkey. sultan.kuzu@istanbul.edu.tr, ORCID: 0000-0001-6577-1584

\section{To cite this document}

Sezici, Z., Yildirim, S.K., (2021). The long-term relationship between renewable energy and economic growth: the case of America. PressAcademia Procedia (PAP), 14, 113-114.

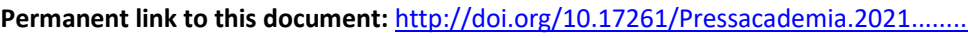

Copyright: Published by PressAcademia and limited licensed re-use rights only.

\section{ABSTRACT}

Purpose- The purpose of this study is to investigate whether there is a relationship between renewable energy consumption, electricity consumption and gross domestic product (GDP) of the United States of America over the period 1965-2019. In this context, renewable energy consumption data was obtained from the British Petroleum Statistical Review of World Energy 2020 report, electricity end-use consumption data acquired from U.S. Energy Information Administration and GDP data were obtained from World Bank.To achieve this goal, we employ Johansen cointegration analysis and after determining that the long-term relationships exist between variables, then causality relationships have examined with the Toda-Yamamoto test. In addition, by establishing a Vector Error Correction Model, it was investigated whether the long-term relationship is adaptable to the short-term.

Methodology- In this study, renewable energy consumption, electricity consumption and GDP variables of the United States of America between 1965 and 2019 were examined. First of all, natural logarithms of all variables were taken to solve the problem of heteroscedasticity, which is frequently encountered in time series. Seasonal effects were not examined, as the variables examined were arranged at an annual frequency. For cointegration analysis used to examine long-term relationships, the series should be non-stationary and can be stationary at the same level (Johansen, 1988). First of all, unit root tests were performed on the 3 variables examined. Among these tests, ADF, PP, KPSS and DF-GLS tests were selected. Then, the appropriate VAR model was established to apply the Johansen cointegration analysis. The lag number of the VAR model was decided by considering both the information criteria and the assumptions of the VAR model. After the VAR model was established, Johansen cointegration analysis was applied, and after the existence of the long-term relationship was determined, the model was continued with the vector error correction model. In addition, causality relationships were also examined with TodaYamamoto. Since the level values of the Toda-Yamamoto series are made (without a difference), there is no loss of information (Toda \& Yamamoto, 1995).

Findings- According to the results of the applied unit root tests, it was determined that all variables were stationary in the first order. It has been determined that the inverse roots of the VAR model established with 3 lags are within the unit circle, that is, it is stable. In addition, when the LM test values of the error terms were examined, it was found that there was no significant autocorrelation. Therefore there is no autocorrelation problem. Finally, when the White test of covariance was applied to the error terms, it was seen that the errors were covariance. According to Johansen cointegration analysis, it was decided that the 3rd model was the most appropriate and two cointegration relations were found. That is, electricity and renewable energy consumption and economic growth are related in the long run. The TodaYamamato test was used to determine the direction of causality. From here, it has been determined that renewable energy consumption and economic growth are the causes of electricity consumption.Contrary to this conclusion, Narayan et al. (2008) found that electricity consumption has a statistically significant positive effect on real GDP in short periods, except for the United States, in the study conducted for the years 1970-2002. This finding implies that, outside the United States, electricity conservation policies will hurt real GDP in the G7 countries. However, in line with our results, Yıldırım (2012) examined the contribution of renewable energy consumption to economic growth for the USA and found that renewable energy consumption increases real GDP. Therefore, we can say that the findings of this article support our econometric findings in our study. In this study, the authors benefited from the Toda-Yamamoto test. Then, the Vector Error Correction Model was established and it was seen that the long-term relationship was adaptable to the short-term. According to results, electricity consumption decreases when renewable energy consumption increases and electricity consumption increases when GDP increases.

Conclusion- Based upon the analysis of the findings it can be concluded that there is a long-run relationship between GDP, electricity consumption and renewable energy consumption variables of US by using the Johansen cointegration test. Also, the Toda-Yamamoto causality results indicate that electricity consumption is a dependent variable and it has a negative correlation between renewable energy 
consumption but a positive correlation between GDP variable. In general, there are two major points of view in the literature. The first one contends that energy consumption has a positive impact on economic growth. Contrary to the first view the second point of view indicates that the cost of energy is a very small proportion of GDP, and energy has no significant impact on economic growth. (Ghali, K. H., \& El-Sakka, M. I. ,2004). Parallel to the second view, a study by Ozturk and Acaravci (2011) investigates the short-run and long-run causality issues between electricity consumption and economic growth for the selected Middle East and North Africa (MENA) countries and the overall results show that there is no relationship between electricity consumption and economic growth in most of the MENA countries. However, Rafindadi and Ozturk's (2017) study concludes that when renewable energy consumption increases Germany's economic growth boost too. Additionally, the causality analysis indicated that there is a feedback effect between renewable energy consumption and economic growth. In line with Rafindadi and Ozturk's study, the empirical findings of our study show that when electricity end-use consumption decreases, renewable energy consumption increases however, GDP decreases too. These findings indicate that renewable energy consumption can replace electricity end-use consumption. Since the US is the biggest economy in the world in terms of GDP, replacing electricity consumption with renewable energy consumption is quite significant.

Keywords: Renewable energy, GDP, electricity, Johansen Cointegration, Vector Error Correction Model

JEL Codes: C01, C58, 013

\section{REFERENCES}

Johansen, S. (1988). Statistical analysis of cointegration vectors. Journal of economic dynamics and control, 12(2-3), 231-254.

Toda, H. Y. ve Yamamoto, T. (1995). Statistical Inference in Vector Autoregressions with Possibly Integrated Process. Journal of Econometrics, $66,225-250$

Ozturk, I., \& Acaravci, A. (2011). Electricity consumption and real GDP causality nexus: Evidence from ARDL bounds testing approach for 11 MENA countries. Applied Energy.

Ertugrul Yildirim, Ş. S. (2012). Energy consumption and economic growth in the USA: Evidence from renewable energy. Renewable and Sustainable Energy Reviews.

Narayan, P. K., Narayan, S., \& Prasad, A. (2008). A structural VAR analysis of electricity consumption and eal GDP: Evidence from the G7 countries. Energy Policy.

Chang, T., Gupta, R., Inglesi-Lotz, R., Simo-Kengneb, B., Smithers, D., \& Trembling, A. (2015). Renewable energy and growth: Evidence from heterogeneous panel of G7 countries using Granger causality. Renewable and Sustainable Energy.

Dorsman, A., Westerman, W., \& Simpson, J. L. (Eds.). (2015). Energy Technology and Valuation Issues. doi:10.1007/978-3-319-13746-9 